\title{
Sensory Assessment of Gayo arabica coffee taste based on various varieties and manual brewing devices
}

\author{
Rahmat Fadhil1 $^{1}$, Diswandi Nurba1 ${ }^{1 D}$, Elya Sukmawati ${ }^{1}$ (i
}

\author{
${ }^{1}$ Universitas Syiah Kuala/USK, Faculty of Agriculture, Department of Agricultural Engineering, Banda Aceh, Indonesia \\ Contact authors: rahhmat.fadhil@unsyiah.ac.id; diswandi@unsyiah.ac.id; elya@mhs.unsyiah.ac.id \\ Received in April 27, 2021 and approved in July 15, 2021
}

\section{ABSTRACT}

Arabica coffee (Coffea arabica) becomes one of the most in-demand types by the community due to its typical taste. The material needed in this study was Gayo Arabica coffee (full wash) obtained from farmers in Bener Meriah, Aceh Province of Indonesia and specially ordered. The right method and coffee brewing device are needed to obtain this typical taste of coffee. One of the coffee brewing methods that keeps developing until now is the manual brewing method. This study aims to find the sensory assessment of Gayo Arabica coffee taste in various varieties with manual brewing devices by using Analytical Hierarchy Process (AHP) method. Manual brewing devices used were Vietnam Drip, French Press, V60, Eva Solo, and Filter, while the chosen varieties are Tim-tim (Gayo 1), Bor-bor (Gayo 2), and P88. The study result showed that based on the preference of product acceptance by the panelists, the most chosen criteria of taste sensory were flavor (0.253), followed by aftertaste $(0.222)$, sweetness (0204), acidity (0.165), and body (0.155). The variety chosen as the best variety with manual brewing was Tim-tim in various manual brewing devices, which are V60 (0.156), French Press (0146), and Eva Solo (0.140). The next alternatives brewing devices were Vietnam Drip (0.127) and Filter (0.109). Thus, it could be concluded that flavor is the top priority that influences Gayo Arabica coffee's taste. Therefore, Tim-tim with manual brewing devices (V60, French Press, and Eva Solo) is preferred over other varieties in this study. This finding also becomes a recommendation that the variety for the best serving of Gayo Arabica coffee brew with the most preferred taste with manual brewing devices is Tim-tim.

Key words: Arabica coffee; Manual brewing; AHP method; Pairwise comparison.

\section{INTRODUCTION}

Coffee is a crop that has been cultivated for a long time by Indonesian people as a livelihood and until now, it continues to experience significant development. Let alone, coffee is a plantation commodity that has high economic value, so that this commodity becomes one of the main sources of the community's economy and foreign exchange. Several coffees are cultivated in Indonesia, which are Robusta, Arabica, and Liberica coffee. Coffee that nowadays has become world's prime coffee is arabica coffee. One of Indonesia's main arabica coffee producers is in Aceh Province, known as Gayo coffee. Three regencies in Aceh become the main producer central for arabica coffee: Central Aceh, Gayo Lues, and Bener Meriah (Fadhil et al., 2018a). The productivity of arabica coffee in the three regencies reaches 700 to $800 \mathrm{~kg} \mathrm{ha}^{-1}$, and all the coffee fields are cultivated by smallholder plantations (Distanbun Aceh, 2013). Arabica coffee dominates the world market up to $70 \%$ due to its typical flavor that causes this coffee's price to be high (Fadhil et al., 2018b).

Coffee taste varies from region to region based on their cultural and social context. According to Carvalho, Moksunova and Spence (2019), measuring the taste of product packaging and serving ware can impact the perceived taste and mouthfeel of different foods and beverages. One of the taste coffee measurement methods uses the cupping assessment method, an assessment based on the coffee characteristics, in this sensory assessment, given a value on a certain scale to measure aroma attributes, sweetness, acidity, body, flavor, balance, and aftertaste (Carvalho; Moksunova; Spence, 2019). The coffee taste is influenced by the aroma, flavor, sweetness, acidity, or overall taste that the consumers enjoy after drinking the coffee, including brewing devices (Giomo et al., 2012).

Today, several brewing methods develop in the community; one is the manual brewing method. These brewing methods have their ways to yield the best coffee taste, so selecting the right coffee brewing method will greatly affect the quality of the taste produced. Therefore, this study is important to determine the taste sensory of Gayo Arabica coffee based on various manual brewing methods using the assessment system with the Analytical Hierarchy Process (AHP) approach.

AHP is a decision support model that Thomas L. Saaty developed. AHP is an optimization model and enjoying the benefits of optimization; moreover, they are properly solved and can generate a globally optimal solution (Wu; $\mathrm{Tu}, 2020)$. This decision support model will be outlined based on a multifactor or multi-criteria problem to be made into a hierarchy. Hierarchy is a representation of a complex problem contained in a multi-level structure. A hierarchy will simplify decisionmaking because it has structured the problems to be more systematic to be solved (Saaty, 2008). There are four basic principles used to solve the AHP problem: making hierarchy, scoring criteria and alternatives, determining the priority, and measuring consistency (Kusrini, 2016). AHP method has been widely applied in many fields of study, such as supply chain management (Mathiyazhagan et al., 2015; 
Piprani; Jaafar; Mohezar-Ali, 2020), employee performance assessment (Ilhami; Rimantho, 2017), decision support system (Mauko; Muslimin; Sugiartawan, 2018), determination of roadwork priority (Kurniawan; Assegaff, 2019), Geographic Information System (Merrouni et al., 2018; Kaur et al., 2020), telecommunication (Ahmadi; Petrudi; Wang, 2017), the capability of modeling (Aburas et al., 2017), food (Ma et al., 2020; Tascioglu et al., 2020; Harini et al., 2018), military (Asghar et al., 2017; Saravanan; Thakkar, 2018) and so on.

This study aims to determine the taste sensory of Gayo Arabica coffee in various varieties and manual brewing devices using the AHP method to generate a recommendation of coffee variety with the best serving method of Gayo arabica coffee brew most preferred taste by the consumers (panelists).

\section{MATERIAL AND METHODS}

\subsection{Devices and Procedure}

Devices used in this research are KRUPS GVX 231 Burr coffee grinder machine, manual coffee brewing devices (Vietnam Drip, French Press, V60, Eva Solo, and Filter), cups, spoons, and container. Materials that were used were Gayo arabica coffee bean (full wash) variety Timtim (Gayo 1), Bor-bor (Gayo 2), and P88 obtained directly from the farmer in the Regency of Bener Meriah at an altitude of 1400 meters above sea level. The coffee bean was then roasted with medium degree and ground with coarseness level 2. The examined criteria are Gayo arabica coffee assessment, including sweetness, flavor, body, acidity, and aftertaste. The sensory assessment was performed by ten panelists with requirements that the panelists are arabica coffee connoisseurs, know the varieties of arabica coffee, differentiate the taste of each variety of arabica coffee, and are not suffering from any disease such as flu and cough, and are not color-blind. According to the Analytical Hierarchy Process (AHP) method, each panelist was given a pairwise comparison questionnaire to perform sensory tests on each coffee brew based on the scale in Table 1. Various manual brewing devices are seen in Figure 1, and the flow diagram of this research is presented in Figure 2.
Table 1: The Fundamental scale of absolute numbers (Saaty, 2013).

\begin{tabular}{|c|c|c|}
\hline $\begin{array}{l}\text { Intensity of } \\
\text { importance }\end{array}$ & Definition & Description \\
\hline 1 & Equal Importance & $\begin{array}{l}\text { Two activities contribute } \\
\text { equally to the objective }\end{array}$ \\
\hline 2 & Weak or slight & \\
\hline 3 & Moderate importance & $\begin{array}{l}\text { Experience and judgment } \\
\text { slightly favor } \\
\text { one activity over another }\end{array}$ \\
\hline 4 & Moderate plus & \\
\hline 5 & Strong importance & $\begin{array}{c}\text { Experience and judgment } \\
\text { strongly favor } \\
\text { one activity over another }\end{array}$ \\
\hline 6 & Strong plus & \\
\hline 7 & $\begin{array}{c}\text { Very strong or } \\
\text { demonstrated importance }\end{array}$ & $\begin{array}{l}\text { An activity is favored } \\
\text { very strongly over } \\
\text { another; its dominance } \\
\text { demonstrated in practice }\end{array}$ \\
\hline 8 & Very, very strong & \\
\hline 9 & Extreme importance & $\begin{array}{l}\text { The evidence favoring } \\
\text { one activity over another } \\
\text { is of the highest possible } \\
\text { order of affirmation }\end{array}$ \\
\hline $\begin{array}{l}\text { Reciprocals } \\
\text { of above }\end{array}$ & $\begin{array}{l}\text { If activity A has one } \\
\text { of the above non-zero } \\
\text { numbers assigned to it } \\
\text { when compared with } \\
\text { activity B, then B has the } \\
\text { reciprocal value when } \\
\text { compared with A }\end{array}$ & A reasonable assumption \\
\hline $1.1-1.9$ & $\begin{array}{l}\text { If the activities are very } \\
\text { Close }\end{array}$ & $\begin{array}{l}\text { It May be difficult to } \\
\text { assign the best value but } \\
\text { when compared with } \\
\text { other contrasting } \\
\text { activities the size of the } \\
\text { small numbers would } \\
\text { not be too noticeable, yet } \\
\text { they can still indicate the } \\
\text { relative importance of the } \\
\text { activities. }\end{array}$ \\
\hline
\end{tabular}

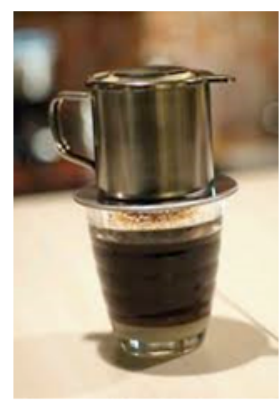

(a)

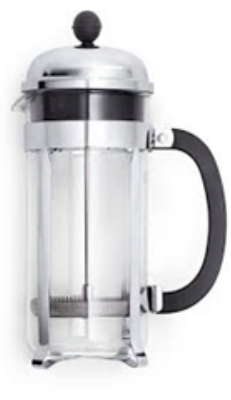

(b)

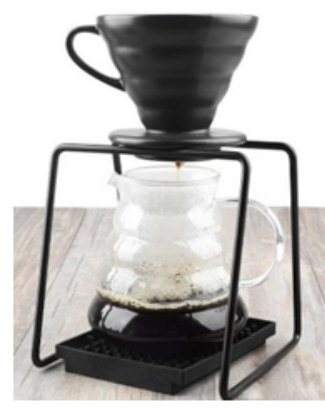

(c)

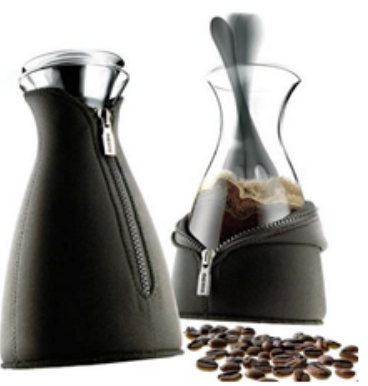

(d)

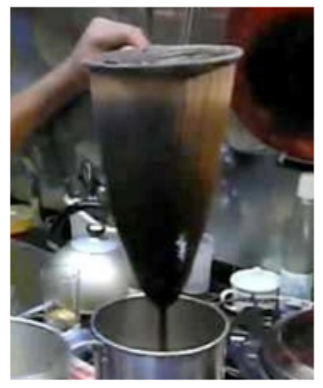

(e)

Figure 1: Coffee Manual Brewing Devices. (a) Vietnam Drip; (b) French Press; (c) V60; (d) Eva Solo; (e) Fabric Filter. 


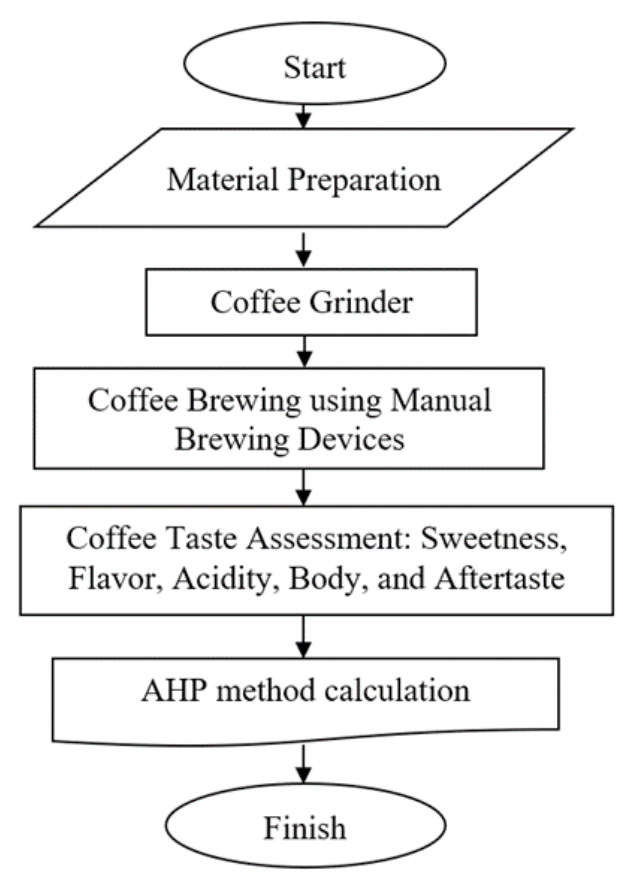

Figure 2: Research flow diagram.

\subsection{Procedure for Using Brewing Devices}

Procedure for using the manual brewing devices that were used to serve a cup of coffee measuring $0.03 \mathrm{~L}$ (standard size of espresso) are as following:

1. Vietnam Drip brewing method is the simplest one among other methods. In this method, $0.01 \mathrm{~kg}$ of ground coffee and $0.15 \mathrm{~L}$ of water at the temperature of $85-90^{\circ} \mathrm{C}$ were prepared. First, the dripper was flushed (flushing), and after the coffee was put and evened, it was covered with a dripper filter. Next, the dripper was poured with $0.03 \mathrm{~L}$ of hot water and was left for 30 seconds (blooming process). Then, all the remaining hot water was poured and was awaited until all the coffee brew stopped dripping.

2. French Press is a brewing device that can remove the coffee grounds with the lid's pressing technique. To serve it, 0.014 $\mathrm{kg}$ of ground coffee and $0.12 \mathrm{~L}$ of water at $85-90{ }^{\circ} \mathrm{C}$ were prepared. First, the French Press was flushed (flushing), and the water is removed. The ground coffee was put into the chamber glass, and then the hot water was poured into the chamber/ plunger until $0.03 \mathrm{~L}$ of the volume was reached. It was left for 30 seconds (blooming) and was poured again with hot water (for 60 seconds), and then was left for 20 seconds (so that the water is completely infiltrated with the coffee), and last, the French Press was slowly pressed (for 20 seconds).

3. V60 method is one of the popular and widely used manual coffee servings that it becomes the reliable basic device of manual coffee brewing. The coffee brewing system in this method uses the principle of dripping. To serve it, $0.012 \mathrm{~kg}$ of coffee (medium fineness), V60 filter, and $0.15 \mathrm{~L}$ of hot water at $75-93{ }^{\circ} \mathrm{C}$ were prepared. The filter was flushed with hot water, and the water was removed. The ground coffee was put into the dripper, and then hot water was poured on the dripper clockwise (avoid side part). After the volume reach $0.03 \mathrm{~L}$ water (40-60 seconds), it was left for 30 seconds and was awaited until the coffee brew stopped dripping.

4. Eva solo has a similarity in principle with the French Press method because there is a process of immersing all the ground coffee in a glass. In this method, $0.03 \mathrm{~kg}$ of ground coffee was put in a glass, and the hot water was poured in (suggested temperature by $85-90^{\circ} \mathrm{C}$ ). Coffee was stirred for $10-20$ seconds, and the lid was attached and was allowed to extract for four minutes.

5. The fabric filter is a method that is still widely used by traditional coffee shops. By $0.015 \mathrm{~kg}$ of the coffee bean was ground in a ratio of $1: 12$ or equal to $0.18 \mathrm{~L}$ of water. The water was boiled then the ground coffee was put in. The heat was reduced for 2 minutes as the coffee grounds were left in the container. The coffee that had been heated was then filtered several times before being served.

\subsection{Decision-Making System of Analytical Hierarchy Process (AHP) method}

Based on the questionnaires given to the panelists, each alternative's significance level was done through pairwise comparison by using a range from $1-9$ (Table 1). The collected questionnaires were then processed using an application (Expert Choice version 11) to calculate the Analytical Hierarchy Process (AHP) to obtain the best decision according to the panelists' preference for acceptance (Expert-choice, 2004). According to Fadhil et al. (2018b), the procedure in the AHP method includes the following steps:

a. Defining the problem and determining the desired solution, then compiling a hierarchy of the problems encountered. Hierarchy is the human ability to understand objects and ideas, identify them, and communicate what they observe.

b. Determining the priority of elements

The first step in determining the priority of elements is to create a pair comparison matrix. Next, the pairwise comparison matrix is filled in using numbers to represent the relative importance of an element to other elements.

c. Synthesis

The considerations for pairwise comparisons are synthesized to obtain overall priorities.

d. Measuring consistency

It is important to know how good consistency is because we don't want judgmental decisions with low decision-making consistency. Things to do in these steps are:

e. Calculate Consistency Index (CI)

with the formula: $\mathrm{CI}=(\lambda \max -\mathrm{n}) / \mathrm{n}-1$ where $\mathrm{n}=$ number of elements

$\max =$ maxim um eigenvalue of the pairwise comparisons matrix 
f. Calculate Consistency Ratio (CR)

with the formula: $\mathrm{CR}=\mathrm{CI} / \mathrm{RI}$

where $\mathrm{CR}=$ Consistency Ratio, $\mathrm{CI}=$ Consistency Index, $\mathrm{RI}=$ Random Index

g. Check the consistency of the hierarchy.

If the value is more than $10 \%$, then the data judgment assessment must be corrected. However, if the consistency ratio (CI/IR) less or equal to $0.1(\mathrm{CR}<0.1)$, then the calculation results can be declared correct. $\mathrm{CR}<0.1$

\section{RESULTS}

\subsection{Taste Assessment}

Based on the processed data, the coffee taste criteria assessment (Table 2) shows that the flavor rank number 1 followed by aftertaste, sweetness, acidity, and the last is the body.

\subsection{Varieties}

The assessment of Gayo arabica coffee varieties (Table 3) shows that Tim-tim varieties rank number 1 following by Bor-bor and P88.

\subsection{Manual Brewing}

Based on the five manual brewing tools used, it is found that the priority types of brewing tools (Table 4) show that V60 is the best brewing tool, and then following by French Press, Eva Solo, Vietnam drip, and Filter.

Figure 3 shows the hierarchy formed from the research on the sensory assessment of Gayo Arabica coffee based on various varieties and manual brewing tools.

\section{DISCUSSIONS}

\subsection{Assessment of Taste Sensory}

According to the assessment of taste sensory of Gayo arabica coffee in various varieties and manual brewing methods, the priority of taste, which mostly influences the panelists' acceptance, is flavor (Table 2). Generally, coffee connoisseurs consider flavor (0.253) as a criterion that becomes a standard of a coffee because it produces the characteristics of taste in the whole coffee. The taste of this coffee is influenced by several ingredients, such as the fat content in coffee contained in the protective wax layer of the beans and the coffee oil. The wax layer contains fatty acids 5-hydroxytryptamine from

Table 2: Assessment criteria for the best arabica coffee taste.

\begin{tabular}{cccccccc}
\hline \multirow{2}{*}{$\begin{array}{c}\text { Elements of } \\
\text { Factor A }\end{array}$} & Sweetness & Flavor & Body & Acidity & Aftertaste & Priorities & Ranking \\
\cline { 2 - 8 } Sweetness & 1.000 & 0.794 & 1.516 & 1.399 & 0.720 & 0.204 & 3 \\
Flavor & 1.259 & 1.000 & 1.813 & 1.349 & 1.149 & 0.253 & 1 \\
Body & 0.660 & 0.552 & 1.000 & 0.960 & 0.871 & 0.155 & 5 \\
Acidity & 0.715 & 0.741 & 1.041 & 1.000 & 0.763 & 0.165 & 4 \\
Aftertaste & 1.389 & 0.871 & 1.149 & 1.311 & 1.000 & 0.222 & 2 \\
\hline
\end{tabular}

Note: Factor A (criterion A) compared to factor B (criterion B).

Table 3: Assessment of Gayo arabica coffee varieties.

\begin{tabular}{cccccccc}
\hline Varieties & Sweetness & Flavor & Body & Acidity & Aftertaste & Priorities & Ranking \\
\hline Tim-tim & 0.501 & 0.446 & 0.426 & 0.429 & 0.412 & 0.282 & 1 \\
Bor-bor & 0.499 & 0.350 & 0.383 & 0.336 & 0.341 & 0.250 & 2 \\
P88 & 0.319 & 0.204 & 0.191 & 0.236 & 0.246 & 0.147 & 3 \\
\hline
\end{tabular}

Table 4: Sensory assessment of Gayo arabica coffee taste based on manual brewing devices.

\begin{tabular}{|c|c|c|c|c|c|}
\hline Manual Brewing Devices & Tim-tim & Bor-bor & P88 & Priorities & Ranking \\
\hline Vietnam Drip & 0.201 & 0.176 & 0.178 & 0.127 & 4 \\
\hline French Press & 0.212 & 0.218 & 0.219 & 0.146 & 2 \\
\hline V60 & 0.210 & 0.254 & 0.228 & 0.156 & 1 \\
\hline Eva Solo & 0.240 & 0.178 & 0.190 & 0.140 & 3 \\
\hline Filter & 0.137 & 0.174 & 0.185 & 0.109 & 5 \\
\hline
\end{tabular}


palmitic, arachidic, behenic, and lignoceric acids. Fat in coffee is one of the chemical compositions of coffee that forms the taste of coffee. Furthermore, caffeine functions as a stimulant compound that tastes bitter, are easily soluble in water, and has fragrant (Hayati; Marliah; Rosita, 2012; Sulistyowati, 2001). These taste characteristics are related to coffee compounds during the extraction that forms a taste buds' taste when swallowed. Factors that create taste characteristics are very diverse; one is roasting level, source of coffee bean, variety, and so on (Fadhil; Nurba, 2019). While several recent studies have illustrated that serving temperature does impact sensory attribute intensities of brewed coffee, brewed coffee samples were served at specific serving temperatures for sensory evaluation can also affect the taste of coffee (Chapko et al., 2018).

The flavor itself is often mentioned with the terms fruity, sour, bitter, rich, or balanced. Today, there is a coffee tasters flavor wheel as a product of collaboration between the Specialty Coffee Association (SCA) and World Coffee Research (WCS) in cupping coffee taste (Masdakaty, 2017). This what makes the flavor a priority criterion in coffee taste sensory. Flavor also becomes the first index when someone drinks coffee. If the flavor alone does not attract interest, someone will doubt to drink the coffee. The overall assessment consistency from the five taste criteria is $\leq 0.1$, which means that the data is consistent and acceptable. Based on the analysis of the sensory assessment criteria of Gayo Arabica coffee taste, it showed that the Flavor criterion is the most important criteria compared to other criteria (Fadhil; Nurba, 2019).

The criterion for 'aftertaste' $(0.222)$ in this sensory coffee test shows that the panelists make it the second criterion after 'flavor', as seen on the analysis result of coffee taste criteria assessment in Table 2. 'Aftertaste' is a term used to express the taste left in the mouth and create an experience of preferred coffee taste, where there are two driving attributes that influence overall fondness to the coffee, which are bitterness and aftertaste (Anggriawan et al., 2020). It is necessary to understand that sometimes the same coffee may give a different aftertaste among coffee connoisseurs. The lingering taste is caused by the overall coffee characters that stopped on the taste buds, such as flavor, acidity, and body (Musika, 2019).

The next criterion is sweetness (0.204), where the swallowed coffee raises a sweet taste. This sweetness is not similar to the sweet taste of sucrose in soft drinks. Coffee sweetness has meant that it will raise a pleasant sweet taste and favor panelists. In this context, the opposites of sweetness are sour, astringent, or unripe (Coffeeland Indonesia, 2018); moreover, the sweet taste gives its sensation from the natural flavor produced (Fadhil; Nurba, 2019).

The next criterion priority is acidity $(0.165)$. Generally, the emerged acidity character is closer to a taste that ever tasted. Thus, emerges a perception of fruity acids, particularly sour fruits, such as oranges, tamarind, and other acidic characters. In general, this acidic character is called sharp (obvious acidity), thin (faint acidity), mild, and neutral (Musika, 2019). It is different from the criterion 'body' $(0.155)$, which refers to the trace of coffee in the mouth. When coffee enters the mouth, particularly between tongue and palate, the character is either thick or light. Other characteristics are often mentioned as full (heavy character), thick (bold character), balanced, buttery, and thin (Musika, 2019). Usually, the thicker the body, the better it is. According to Fadhil and Nurba (2019), analysis of Gayo Arabica coffee taste's sensory assessment criteria showed that the body criterion is not the most important criteria.

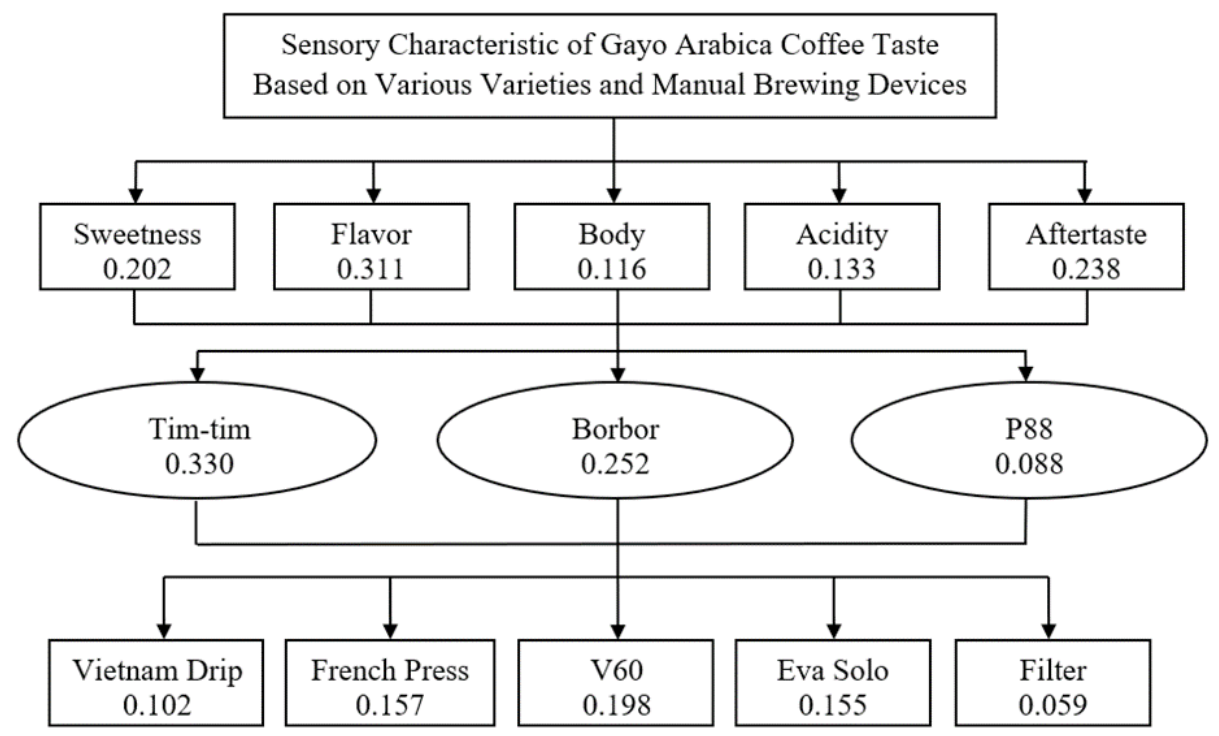

Figure 3: The hierarchical structure of Gayo arabica coffee taste sensory 
According to Leroy et al. (2006), taste can be measured by senses and may be influenced by physical and chemical properties, agronomy, and technological factors. Panelists' capability very influences quality assessment from a sensory test in doing the sensory evaluation itself. Coffee sensory quality assessment needs practice, particularly the 'flavor' of a coffee cup that combines multi-aromatic composition in coffee. The flavor shows the specific properties from the combination of aroma, acidity, and aftertaste (Coffeeland Indonesia, 2018). Aroma tasted by the tongue will directly flow to the nose and determine the quality and complexity. Thus, the coffee connoisseurs can directly find out the taste of coffee.

\subsection{Varieties}

According to the panelists' assessment, the most preferred variety shows that Tim-tim is the preferred variety (0.282). According to Hayati, Marliah and Rosita, (2012), Tim-tim has higher fat content, so that this variety of coffee bean has the best flavor that also can be considered as the most preferred by the coffee connoisseurs, compared to Borbor (0.250) and P88 (0.147) (Table 3). Because of the typical aroma from Tim-tim, everybody wants to brew it. Some panelists' opinions stated that Tim-tim does not taste too bitter than coffee variety P88 and Bor-bor. Besides, the sweetness comes from the Gayo coffee variety Timtim increases the appetite of the coffee drinker. This opinion is also following a study by Wahyuni, Karim and Anhar (2013), which stated that the result of score evaluation of taste criteria of arabica coffee Tim-tim at an altitude of $<1200 \mathrm{MSL}$ is more preferred by the coffee connoisseurs, different from variety P88 and Bor-bor which have higher bitterness. However, variety P88 has a more prominent criterion of acidity, as Hayati Marliah and Rosita (2012) stated, that the one with the highest acidity is P88. In contrast, Bor-bor has a thicker body compared to other varieties.

\subsection{Manual Brewing}

Sensory assessment of Gayo arabica coffee taste based on manual brewing device shows that V60 $(0.156)$ is the most preferred brewing device (Table 4). This brewing device applies a dripper principle widely used in coffee brewing. In addition, its downward conical design with one extraction hole in one point and helical form facilitates the water flow during the extraction process. Coffee brewed with V60 is favored by expert coffee connoisseurs due to its simplicity in experimenting with the pouring style and taste character (Musika, 2019). Like Chemex (a V60-like brewing device), the V60 method also produces a satisfying character in every single-origin it brews. Clean cup, light, and flavor are the results that V60 generally gives. Thus, it is no surprise that this method is favored by manual brew (Masdakaty, 2016).
Brewing device French Press (0.146) becomes the second priority after V60. French Press is a brewing device with the soaking method principle or full immersion, where the hot water will soak the coffee for a certain period. French Press is different from other methods because this method does not use filter paper or cone. The given result is a taste of rich, soft, a bit oily (Yuliandri, 2015). This method can also cause more oil in the ground coffee to dissolve in the brewing yield and has a heavier texture or body.

Next, in the third place is the manual brewing device Eva Solo (0.140). Eva Solo has a little similarity with French Press because it uses the immersion principle. In addition, Eva Solo uses a convex filter that downwards into a brewing chamber. The glass container for brewing has similarities with the brewing device Chemex, but Eva Solo does not have a handle like Chemex (Masdakaty, 2016). The coffee resulted is also spared from dregs because after being stirred, the coffee will be covered with the lid. Besides, as a part of its design, the neoprene jacket also functions to keep the temperature of coffee inside stay warm. Therefore, it is necessary to be careful when pouring the coffee so that the stirred coffee grounds will not be brought with the poured coffee.

The next is the brewing device Vietnam Drip (0.127), which has the uniqueness of the dripper. Each drop of coffee extraction that drips into the cup will prevent mixing with coffee grounds. This makes the aroma in coffee more prominent, although it will have to wait longer than other devices. Whereas the least chosen is the brewing device with filter (0.109). The coffee filter used is fabric and does not use a filter from aluminum or iron. This reduces the risk of leaving coffee ground from the brewed ground coffee. This technique is carried out by the principle of passing water on ground coffee in the filter. Moreover, water is poured slowly into the powder, dissolves the coffee flavoring compound in ground coffee, and penetrates the filter pores (Fibrianto et al., 2019). According to the panelists' opinion, the result obtained that the coffee produced with filter is less favored because the coffee brew resulted is not thick enough. Hence, it can be understood that the taste of coffee is very much influenced by the brewing technique to produce suitable with a needed consumer (Musika, 2018).

Implementation of the AHP method in multi-criteria decision-making is easy to use because it can handle several criteria with a certain allowable consistency score (Upadhyay, 2017). The hierarchy structure of Gayo arabica coffee taste sensory based on the varieties and manual brewing device is seen in Figure 3. The study result clearly shows that the taste is very much influenced by the selection of brewing device, as Sunarharum and Farhan (2019) stated that the difference in coffee manual brewing technique would affect the variation of sensory profile in the produced brew. All the data that have been tested have a score of consistency of $\leq 0.1$, so all the data are consistent and acceptable. 


\section{CONCLUSIONS}

Sensory assessment of Gayo arabica coffee based on various variety and manual brewing device by using Analytical Hierarchy Process (AHP) shows that criteria of taste sensory that mostly influence product (coffee brew) acceptance respectively are flavor $(0.311)$, aftertaste $(0.238)$, sweetness $(0.202)$, acidity (0.133), and body (0.116). Therefore, the best coffee variety with chosen manual brewing is Tim-tim, with manual brewing devices V60 (0.198), French Press (0.157), and Eva Solo (0.155). And for the next alternative brewing device, there are Vietnam Drip (0.102) and Filter (0.059). This result confirms two things at once; first, the flavor is the most prioritized criterion that influences the taste of Gayo arabica coffee, and next, Tim-tim variety with manual brewing device (V60, French Press, and Eva Solo) is the most favored variety than others. Therefore, a recommendation for the best manual brewing of Gayo arabica coffee is to use the Tim-tim variety because it has taste advantages over other varieties.

\section{ACKNOWLEDGEMENTS}

The author would like to express his gratitude and highest appreciation to KEMENRISTEK BRIN and LPPM Unsyiah for the support of the INSINAS research for the 2021 fiscal year Number 15/E1/KPT/2021.

\section{REFERENCES}

ABURAS, M. M. et al. Improving the capability of an integrated ca- markov model to simulate spatio-temporal urban growth trends using an analytical hierarchy process and frequency ratio. International Journal of Applied Erath Observation and Geoinformation, 59:65-78, 2017.

AHMADI, H. B.; PETRUDI, S. H. H.; WANG, X. Integrating sustainability into supplier selection with analytical hierarchy process and improved grey relational analysis: a case of telcom industry. International Journal of Advanced Manufacturing Technology, 90:2413-2427, 2017.

ANGGRIAWAN, R. et al. Process optimisation of lowcaffeine coffee using steam treatment. Preprints, $2020050254,2020$.

ASGHAR, A.; MUHAMMAD, N.; SALMAN, A. Selection of a fighter aircraft to improve the effectiveness of air combat in the war on terror: Pakistan air force - a case in point. International Journal of the Analytic Hierarchy Process, 9(2):63-74, 2017.

CARVALHO, F. M.; MOKSUNOVA, V.; SPENCE, C. Cup texture influences taste and tactile judgments in the evaluation of specialty coffee, Food Quality and Preference, 81:103841, 2019.

CHAPKO, M, J.; SEO, H, S. Characterizing product temperature-dependent sensory perception of brewed coffee beverages: Descriptive sensory analysis. Food Research International, 121:612-621, 2018.

COFFEELAND INDONESIA. Mengenal Cita Rasa Kopi (Knowing Coffee Taste). 2018. Available in: https:// coffeeland.co.id/mengenal-cita-rasa-kopi-coffee-cupping/, Access in: August, 11, 2021.

DISTANBUN ACEH. Prospek pengembangan perkebunan kopi di provinsi aceh (Development Prospect of Coffee Plantation in Aceh Province). 2013. Available in: https:// distanbun.acehprov.go.id/berita/kategori/daerah/44160ton-kopi-gayo-terancam-tdak-diveli-buyer. Access in: August, 11, 2021.

EXPERT-CHOICE. Expert choice version 11. Expert choice resource aligner. Expert Choice, Inc., 2004. Available in: $<$ https://www.expertchoice.com/ahp-software $>$. Access in: August, 11, 2021.

FADHIL, R. et al. Formulation for development strategy of gayo coffe agroindustry institution using interpretive structural modelling (ISM). Acta Universitatis Agriculturae et Silviculturae Mendelianae Brunensis, 66(2):487-495, 2018a.

FADHIL, R. et al. A prospective strategy for institutional development of Gayo coffee agroindustry in Aceh province, Indonesia. Bulgarian Journal of Agricultural Science, 24(6):959-966, $2018 \mathrm{~b}$.

FADHIL, R. et al. Development strategy for a quality management system of gayo coffee agro-industry using soft systems methodology. Periodica Polytechnica Social and Management Sciences, 26(2):168-178, 2018.

FADHIL, R.; NURBA, D. Comparison of gayo arabica coffee taste sensory scoring system between eckenrode and fuzzy-eckenrode methods. International Conference on Agricultural Technology, Engineering, and Environmental Science (ICATES), 365:012040, 2019.

FIBRIANTO, K. et al. Brewing time and temperature optimization of robusta dampit coffee on several drip techniques. IOP Conference Series: Earth and Environmental Science, 230:012035, 2019.

GIOMO, G. S. et al. Evaluation of green bean physical characteristics and beverage quality of arabica coffee varieties in Brazil. 24th International Conference on Coffee Science. $12^{\text {th }}-16$ th November, San Jose, Costa Rica. 2012. 409p. 
HARINI, H. et al. Constraint factors of food competitiveness in java island: AHP approach, Journal of Applied Economics in Developing Countries, 3(2):67-72, 2018.

HAYATI, R.; MARLIAH, A.; ROSITA, F. Sifat kimia dan evaluasi sensori bubuk kopi arabika (Chemical characteristics and sensory evaluation of arabica coffee powder). Jurnal Floratek, 7:66-75, 2012.

ILHAMI, R. S.; RIMANTHO, D. Penilaian kinerja karyawan dengan metode AHP dan rating scale (Assessment of Employee Performance with AHP and Rating Scale Methods). Jurnal Optimasi Sistem Industri, 16(2):150$157,2017$.

KAUR, L. et al. Groundwater potential assessment of an alluvial aquifer in Yamuna subbasin (Panipat region) using remote sensing and GIS techniques in conjunction with analytical hierarchy process (AHP) and catastrophe theory (CT). Ecological Indicators, 110:105850, 2020.

KURNIAWAN, I.; ASSEGAFF, S. Analisis dan perancangan sistem pendukung keputusan penentuan prioritas perbaikan jalan pada pemerintah daerah kabupaten batang hari dengan metode AHP (Anaytical Hierarchy Process). Jurnal Manajemen Sistem Informasi, 4(3):313-325, 2019.

KUSRINI, K. Konsep dan Aplikasi Sistem Pendukung Keputusan (Concept and Application of Decision Support System). Penerbit Andi, Yogyakarta, 2016.

LEROY, T. et al. Genetics of coffee quality. Brazilian Journal of Plant Physiology, 18(1):229-242, 2006.

MA, B. et al. Risk early warning and control of food safety based on an improved analytic hierarchy process integrating quality control analysis method, Food Control, 108:106824, 2020.

MASDAKATY, Y. Apa itu flavor wheel dan bagaimana cara menggunakannya. 2017. Available in: $<$ https://majalah. ottencoffee.co.id/apa-itu-flavor-wheel-dan-bagaimana-caramenggunakannya/>. Access in: October 6, 2020.

MASDAKATY, Y. 5 Metode Seduh dan Jodohnnya Kopi. 2016. Available in: https://majalah.ottencoffee.co.id/5metode-seduh-dan-jodoh-kopinya/. Access in: August, 11, 2021.

MATHIYAZHAGAN, K. et al. Application of analytical hierarchy process to evaluate pressures to implement green supply chain management. Journal of Cleaner Production, 107:229-236, 2015.

MAUKO, A.; MUSLIMIN, B.; SUGIARTAWAN, P. Decision support system in LQ45 Stock Selection Group by Using AHP, Promethee, and BORDA Methods. Jurnal
Sistem Informasi dan Komputer Terapan Indonesia (JSIKTI), 1(1):25-34, 2018.

MERROUNI, A. A. et al. Large scale PV sites selection by combining gis and analytical hierarchy process case study: Eastern Morocco. Renewable Energy, 119:863-873, 2018.

MUSIKA, Y. A. Adakah uji kualitas kopi selain uji Organoleptik (Is there a coffee quality test other than the Organoleptic test). 2018. Available in: $<$ https:// majalah.ottencoffee.co.id/adakah-uji-kualitas-kopi-selainuji-organoleptik/>. Access in: October 6, 2020.

MUSIKA, Y. A. Apa yang sering dibincangkan para penikmat kopi. 2019. Available in: https://majalah. ottencoffee.co.id/apa-yang-sering-dibincangkan-parapenikmat-kopi/. Access in: November, 19, 2020.

PIPRANI, A. Z.; JAAFAR, N. I.; MOHEZAR-ALI, S. Prioritising resilient capability factors of dealing with supply chain disruptions: an analytical hierarchy process (AHP) application in the textile industry. Benchmarking: An International Journal, 27(9):2537-2563, 2020.

SAATY, T. L. Decision making for leaders: the analytic hierarchy process for decisions in a complex world. Kindle Edition. Pittsburgh, Pennsylvania: RWS Publications, 2013. 342p.

SAATY, T. L. Decision making with the analytic hierarchy process. International Journal of Services Sciences, 1(1):83-98, 2008

SARAVANAN, J.; THAKKAR, J. J. An integrated approach for lead time reduction of military aircraft major overhaul: A case of ABC Company. International Journal of Quality \& Reliability Management, 35(1):2-33, 2018.

SULISTYOWATI, S. Faktor yang berperan terhadap cita rasa seduhan kopi (Factors that Influence the Taste of Coffee Brew). Warta Pusat Penelitian Kopi dan Kakao Indonesia, 17(2):138-148, 2001.

SUNARHARUM, W. B.; FARHAN, M. Effect of manual brewing techniques on the sensory profiles of Arabica coffees (Aceh Gayo wine process and Bali Kintamani honey process). IOP Conference Series: Earth and Environmental Science, 454:012099, 2019.

TASCIOGLU, Y. et al. Analysis of buffalo breeders decisions in turkey with Analytical hierarchy process. Pakistan Journal of Agricultural Sciences, 57(1):315-323, 2020.

UPADHYAY, K. Application of analytical hierarchy process in evaluation of best sewage treatment plant. International Journal of Science and Research, 6(6):259-264, 2017. 
WAHYUNI, E.; KARIM, A.; ANHAR, A. Analisis citarasa kopi arabika organik pada beberapa ketinggian tempat dan cara pengolahannya di dataran tinggi gayo. Jurnal Manajemen Sumberdaya Lahan, 2(3):261-265, 2013.

WU, Z, B.; TU, J. Managing transivity andconsistency of preferences in AHP group decision making based on minmum modifications. Journal Information Fusion, 67:125-135, 2020.

YULIANDRI, T. M. Cara yang benar menggunakan french press. 2015. Available in: <https://majalah. ottencoffee.co.id/cara-yang-benar-menggunakan-frenchpress/>. Access in: November 19, 2020. 